\title{
Evaluation of Tube Thoracostomy Interventions Applied in the Emergency Department
} Acil Serviste Uygulanan Tüp Torakostomi Girișimlerinin Değerlendirilmesi

\author{
(D) Hüseyin Ergençl1, (D) Banu Karakuș Yılmaz² \\ IUniversity of Health Sciences Turkey, Haseki High Spesiality Training and Research Hospital, Clinic of Emergency Medicine, İstanbul, Turkey \\ 2University of Health Sciences Turkey, Şişli Hamidiye Etfal High Spesiality Training and Research Hospital, Clinic of Emergency Medicine, İstanbul, Turkey
}

\begin{abstract}
Objective: This study examined the demographic and clinical characteristics and complications of patients undergoing tube thoracostomy (TT) in the emergency department (ED).

Method: This retrospective study included a total of 263 patients who underwent TT performed by emergency physicians within a 2-year study period in the ED of University of Health Sciences Turkey Șișli Hamidiye Etfal Training and Research Hospital. Demographic characteristics of the patients who underwent TT, diagnosis on which the indication for TT was based, mechanisms responsible, morbidities, and complications observed were examined.

Results: The mean age of the patients included in the study was $35.89 \pm 17.47$ years and $224(85.2 \%)$ patients were male, while 39 (14.8\%) patients were female. Indications for TT in the ED were pneumothorax in 174 patients, hemopneumothorax in 74 patients, hemothorax in 10 patients, and empyema/effusion in 5 patients. TT was performed due to non-traumatic causes in 152 (58\%) patients and traumatic causes in 111 (42\%) patients. The non-traumatic causes were spontaneous pneumothorax in 134 patients, iatrogenic in 12 patients, and empyema/effusion secondary to comorbidities and infections in 5 patients. Complications due to TT occurred in only eight (3\%) patients.

Conclusion: The most common indication for TT in the ED was pneumothorax, whereas the main etiology was non-traumatic causes. The application of TT procedures by emergency physicians did not increase the rate of complications since a complication rate of $3 \%$ was associated with the procedure.

Keywords: Emergency room, thoracostomy, chest tube, pneumothorax, hemothorax
\end{abstract}

\section{öz}

Amaç: Bu çalıșmada, acil tıp kliniğinde tüp torakostomi uygulanan hastalarda demografik ve klinik özelikler ile komplikasyonların incelenmesi amaçlandı.

Yöntem: Retrospektif olarak yapılan bu çalıșmaya Sağlık Bilimleri Üniversitesi Şişli Hamidiye Etfal Eğitim ve Araștırma Hastanesi Acil Tıp Kliniği'nde 2 yıllık süreçte acil tıp hekimleri tarafından tüp torakostomi uygulandığı tespit edilen 263 hasta dahil edildi. Tüp torakostomi uygulanmış hastaların demografik özellikleri, tüp torakostomi uygulanma tanıları, oluş mekanizmaları, morbidite ve komplikasyonlar incelendi.

Bulgular: Çalıșmaya dahil edilen hastaların yaș ortalaması 35,89 \pm 17,47 olup hastaların 224'ü (\%85,2) erkek, 39'u (\%14,8) kadın idi. Acil serviste tüp torakostomi uygulama endikasyonları olarak 174 hastada pnömotoraks, 74 hastada hemopnömotoraks, 10 hastada hemotoraks ve 5 hastada ampiyem/efüzyon mevcut idi. Tüp torakostomi uygulanan hastalarda endikasyonları ortaya çıkaran etyolojik mekanizmalar incelendiğinde; 152 hastada (\%58) non-travmatik, 111 hastada (\%42) travmatik nedenler saptandı. Ek olarak, non-travmatik nedenler olarak sıklık sırasına göre 134 hastada spontan pnömotoraks, 12 hastada iyatrojenik ve 5 hastada komorbit ve enfeksiyonlara sekonder gelișen ampiyem/efüzyon mevcut idi. Tüp torakostomiye bağlı yalnızca 8 hastada (\%3) komplikasyon geliștiği saptandı.

Cite as: Ergenç H, Karakuş Yılmaz B. Evaluation of Tube Thoracostomy Interventions Applied in the Emergency Department. IKSSTD 2021;13(3):199-206

๑Copyright 2021 by the Istanbul Kanuni Sultan Süleyman Training and Research Hospital / Medical Journal of Istanbul Kanuni Sultan Suleyman published by Galenos Publishing House.

๑Telif Hakkı 2021 İstanbul Kanuni Sultan Süleyman Eğitim ve Araștırma Hastanesi / Istanbul Kanuni Sultan Süleyman Tıp Dergisi, Galenos Yayınevi tarafından basılmıștr. 
Sonuç: Acil serviste tüp torakostomi uygulama endikasyonları en sık pnömotoraks nedeniyle olup etiyolojide non-travmatik nedenler bașı çekmektedir. Ayrıca, tüp torakostomi girișimlerinin acil tıp hekimleri tarafından uygulanmasının komplikasyon arttırıcı bir faktör olmadığı ve işlemin komplikasyon oranının \%3 gibi öngörülebilir düzeyde olduğu bulunmuştur.

Anahtar kelimeler: Acil servis, torakostomi, göğüs tüpü, pnömotoraks, hemotoraks

\section{INTRODUCTION}

Tube thoracostomy (TT) is a surgical procedure used to provide one-way drainage of the pleural space with closed drainage systems. There are many indications for TT, including pneumothorax, hemothorax, hemopneumothorax, effusion, and empyema, among others (1). The primary purpose of TT is to evacuate air or fluid, such as blood, lymph, or pus that may have accumulated in the pleural cavity due to various etiologies. However, for therapeutic purposes, medications can also be administered through the tube ${ }^{(1,2)}$. Although TT is technically perceived as an easy procedure, its performance can be challenging for physicians in the presence of obesity or in situations that may cause some anatomical difficulties, such as pleural adhesions. During the procedure, it may be necessary to use different imaging methods, such as ultrasonography. Even if the tube is correctly placed, it may be difficult to direct it to the desired area. TT procedure provides a safe and effective drainage when applied according to surgical principles ${ }^{(3)}$.

$\mathrm{TT}$ is an invasive procedure and as a result, complications may arise due to insufficient knowledge of thoracic anatomy, education, or experience. Fatal complications can occur during or after the tube insertion and these complications can be either technical or infective ${ }^{(4,5)}$. Depending on the TT technique, complication rates may increase ${ }^{(6,7)}$. Paying attention to simple surgical principles and sterility protocols during the procedure will increase the efficiency of the procedure and prevent many complications ${ }^{(4)}$.

TT is the most common surgical procedure in thoracic surgery. Specialists may need to apply TT in certain cases, such as life-saving procedures, general surgeries, anesthesia, emergency medicine, chest disease, and thoracic surgery ${ }^{(8)}$. Regardless of whether an accumulation in the pleural cavity result from acute trauma or chronic malignant leakage, chest tube placement allows continuous and/or largevolume drainage until the underlying pathology can be examined and treated. The list of specific treatable etiologies is extensive and patients are at a significant risk of major morbidity or mortality if timely intervention is not provided (9). Therefore, TT is among the primary surgical interventions applied in cases of thoracic trauma. When performed with the appropriate technique and under proper conditions, more extensive surgical procedures are not needed in most cases ${ }^{(10)}$. This study examined the demographic and clinical characteristics and complications of patients undergoing TT performed by emergency physicians in an emergency department (ED).

\section{METHOD}

In this study, data of a total of 263 patients who underwent TT in the Emergency Medicine Clinic of our hospital between January 1, 2015 and December 31, 2016 were obtained from the patient files in the hospital archive and the hospital's electronic records and examined retrospectively. The study was designed according to the principles of the Declaration of Helsinki. It was initiated after obtaining approval from the University of Health Sciences Turkey, Şişli Hamidiye Etfal Training and Research Hospital Ethics Committee on October 18, 2016 with the approval number 1289.

Demographic characteristics (age and sex) of patients aged $\geq 16$ years who underwent TT performed by emergency physicians in the ED, diagnosis on which the indication for TT was based, mechanisms responsible, use of tobacco, duration of stay in the ED, morbidities, and complications during the follow-up were recorded retrospectively. The mechanisms (traumatic or non-traumatic) responsible for the indication of TT were recorded. In addition, patients who were admitted to the Emergency Medicine Clinic due to trauma and underwent emergency surgery due to hemodynamic instability as well as patients who underwent TT at the Thoracic Surgery Clinic or Cardiovascular Surgery Clinic were excluded from the study.

\section{Statistical Analysis}

The data were analyzed using SPSS Statistics for Windows, version 15.0 (SPSS Inc., Chicago, IL, USA). Descriptive statistics, such as means \pm standard deviations, minimum and maximum values, frequency distributions, and percentages (\%), were calculated. Normally distributed data were analyzed by chi-squared and Student's t-tests, whereas non-normally distributed data were analyzed by MannWhitney $U$ test. In all analyses, $p<0.05$ was considered statistically significant. 


\section{RESULTS}

A total of 263 patients ( $\geq 16$ years old) comprising 224 (85.2\%) males and 39 (14.8\%) females, who underwent TT, were included in the study. The mean age of the study population was $35.89 \pm 17.47$ years and was significantly different between male and female patients $(34.88 \pm 16.50$ years vs. $41.67 \pm 21.59$ years, respectively; $p=0.025$ ) (Table 1 ).

TT was applied in the ED due to pneumothorax in 174 patients (66.2\%), hemopneumothorax in 74 (28.1\%) patients, hemothorax in $10(3.8 \%)$ patients, and empyema/effusion in $5(1.9 \%)$ patients (Table 2$)$.

The etiology was non-traumatic (spontaneous, iatrogenic, barotrauma, comorbidity, or infection) in $152(58 \%)$ patients and traumatic in 111 (42\%) patients (Table 2).

The most common reason for the requirement of TT was spontaneous pneumothorax (134 patients; 51\%), followed by detection of pneumothorax, hemothorax, or hemopneumothorax after traumatic events (1ll patients; 42.2\%). Twelve (4.6\%) patients underwent TT due to an iatrogenic pneumothorax that developed after various interventional procedures related to the thorax under outpatient conditions. TT was performed in 5 (1.9\%) patients

Table 1. Demographic characteristics of patients undergoing tube thoracostomy

\begin{tabular}{|l|l|l|}
\hline Gender & $\mathbf{n}(\%)$ & $\begin{array}{l}\text { Age (years) mean } \\
\mathbf{\pm S D}(\mathrm{min} / \mathrm{max})\end{array}$ \\
\hline Female & $39(14.8)$ & $41.67 \pm 21.59$ (min: $17 /$ max: 90) \\
\hline Male & $224(85.2)$ & $34.88 \pm 16.5$ (min: $16 /$ max: 90) \\
\hline Total & $263(100)$ & $35.89 \pm 17.47$ (min: $16 / \max : 90)$ \\
\hline \multicolumn{2}{|l}{ SD: Standard deviation } \\
\hline
\end{tabular}

Table 2. Indications for tube thoracostomy and mechanisms responsible

\begin{tabular}{|l|l|l|}
\hline Indication & $\mathbf{n}$ & \% \\
\hline Pneumothorax & 174 & 66.2 \\
Hemopneumothorax & 74 & 28.1 \\
Hemothorax & 10 & 3.8 \\
Effusion + empyema & 5 & 1.9 \\
\hline Total & 263 & 100 \\
\hline Mechanism & & \\
\hline Spontaneous & 134 & 51 \\
Traumatic & 111 & 42.2 \\
latrogenic & 12 & 4.6 \\
Comorbidity and infection & 5 & 1.9 \\
Barotrauma & 1 & 0.4 \\
\hline Total & 263 & 100 \\
\hline
\end{tabular}

due to respiratory distress caused by effusions secondary to comorbid diseases and infections and in $1(0.4 \%)$ patient due to pneumothorax that developed with barotrauma after intubation in the ED (Table 2).

TT was applied to the right and left hemithorax in 92 $(52.9 \%)$ and 81 (46.6\%) of the 174 patients diagnosed with pneumothorax, respectively, and in both the right and left hemithorax in 1 (0.6\%) patient diagnosed with bilateral pneumothorax.

The 134 patients who underwent TT due to spontaneous pneumothorax comprised 117 males and 17 females. The mean age of these patients was $29.91 \pm 14.02$ years and there was no significant age difference between the male and female patients (30.53 \pm 14.40 years vs. $25.71 \pm 10.43$ years; $p=0.186)$. With regard to the affected hemithorax in the 134 patients who underwent TT with a diagnosis of spontaneous pneumothorax, 73 (54.5\%) and 61 (45.5\%) had pathologies in the right and left hemithorax, respectively.

Of the 134 patients who underwent TT with a diagnosis of spontaneous pneumothorax, 20 (14.9\%) were treated with ipsilateral TT due to recurrent spontaneous pneumothorax, whereas the remaining 114 (85.1\%) patients received treatment for the first occurrence of spontaneous pneumothorax. The patients undergoing TT with a diagnosis of spontaneous pneumothorax comprised 81 (60.4\%) smokers and 53 (39.6\%) non-smokers. In addition, 13 (65\%) of the 20 patients who underwent TT due to recurrent pneumothorax were smokers, whereas 7 (35\%) were nonsmokers (Figure 1).

Nineteen of the 27 patients who underwent TT with a diagnosis of traumatic pneumothorax developed pneumothorax secondary to blunt trauma and the mechanism of trauma in eight (42.10\%) of these cases was penetrating injuries due to stab injuries. The mechanisms of trauma in patients who developed pneumothorax secondary to blunt trauma were falling in $9(47.4 \%)$ cases, traffic

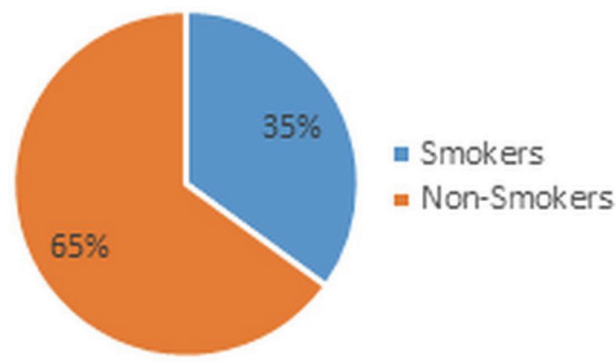

Figure 1. Relationship between recurrent pneumothorax and smoking 
accidents in $6(31.6 \%)$ cases, and assault in $4(21 \%)$ cases. No fractures were detected in 17 (63\%) of the 27 patients diagnosed with traumatic pneumothorax, whereas a single rib fracture was detected in 1 (3.7\%) patient, and 9 (33.3\%) patients had multiple costal fractures. A total of 111 patients comprising 95 (85.6\%) males and 16 (14.4\%) females, with a mean age of $39.48 \pm 17.61$ years (range: 16-90 years), were admitted to the ED due to trauma. The mean age was significantly different between male and female patients ( $52.87 \pm 17.27$ years vs. $37.22 \pm 16.73$ years, respectively; $\mathrm{p}=0.001)$.

Fifty-four (48.6\%) of the 111 trauma patients had right hemithorax injuries and the remaining 53 (47.7\%) had left hemithorax injuries. TT was applied in both the left and right hemithorax in four (3.6\%) patients. Of the 111 patients with thoracic trauma, TT was performed in $74(66.7 \%)$ patients due to the diagnosis of hemopneumothorax, 27 (24.3\%) patients due to pneumothorax, and 10 (9.0\%) patients due to hemothorax (Figure 2).

Penetrating injuries were the most common mechanism of trauma and were seen in 42 (37.8\%) of the 111 patients who underwent TT due to trauma, followed by traffic accidents in $25(22.5 \%)$ patients, falling in $22(19.8 \%)$ patients, gunshot wounds in 16 (14.4\%) patients, and assault in $6(5.4 \%)$ patients (Figure 3).

Among the 53 blunt trauma patients, TT was performed due to hemothorax in $4(7.5 \%)$ patients, pneumothorax in $19(35.8 \%)$ patients, and hemopneumothorax in 30 (56.6\%) patients. Of the 58 penetrating trauma patients, 6 (10.3\%) were diagnosed with hemothorax, 8 (13.8\%) with pneumothorax, and 44 (75.9\%) with hemopneumothorax.

In the patients who underwent $\mathrm{TT}$ due to trauma, although no rib or scapula fractures were found in $74(66.7 \%)$ of the patients, 37 (33.3\%) had either single or multiple fractures of the rib or scapula, $4(3.6 \%)$ had a single rib fracture, 32 (28.8\%) had multiple rib fractures, and $1(0.9 \%)$ had an isolated scapula fracture.

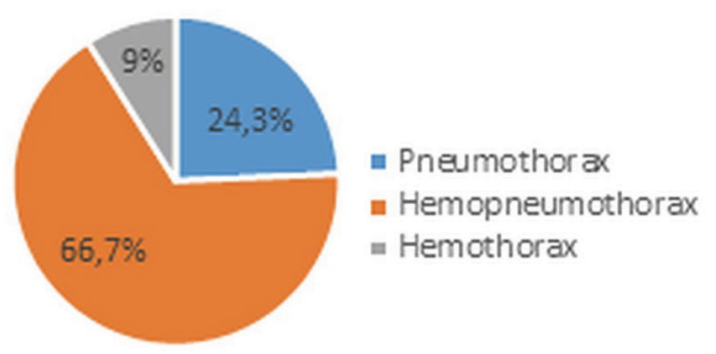

Figure 2. Distribution of tube thoracostomy indications due to trauma type
With regard to the mechanisms of trauma, the thorax pathologies necessitating TT comprised pneumothoraces and hemopneumothoraces in $6(24 \%)$ and 19 (76\%) of the 25 patients who underwent TT after traffic accidents, respectively. Among the 22 patients with fall-related injuries, 10 (45.5\%) had hemopneumothorax, 9 (40.9\%) had pneumothorax, and 3 (13.6\%) had hemothorax. TT was performed due to a diagnosis of pneumothorax in $4(66.7 \%)$ of the 6 assault patients, hemothorax in 1 (16.7\%) patient, and hemopneumothorax in 1 (16.7\%) patient. The indications for TT were hemopneumothorax and hemothorax in 13 (81.3\%) and 3 (18.8\%) of the 16 patients with gunshot injuries, respectively. The pathology was hemopneumothorax in $31(73.8 \%)$ of the 42 patients who underwent TT after stab wounds, pneumothorax in $8(19.0 \%)$ patients, and hemothorax in 3 (7.1\%) patients (Table 3 ).

There were no complications in 255 (97\%) patients who underwent TT, whereas the remaining $8(3 \%)$ patients developed complications, as shown in Table 4. No complication occurred in 167 (96\%) of the 174 patients who underwent TT with a diagnosis of pneumothorax, whereas complications developed in the remaining 7 (4\%) patients. In addition, 73 (98.6\%) of the 74 patients with hemopneumothorax had no complication, whereas only $1(1.4 \%)$ patient developed complications.

\section{DISCUSSION}

There are many indications for TT, including pneumothorax, hemothorax, and malignant effusion, and the application of this procedure in cases with these pathologies in the ED is a lifesaving intervention that requires a great deal of experience (11).

Studies on TT procedures performed in EDs have reported similar results in terms of demographic characteristics ${ }^{112-}$ 14). Şentürk et al. ${ }^{(12)}$ conducted a study on 216 patients who underwent $\mathrm{TT}$ in the ED, reporting that 174 (80.5\%) were

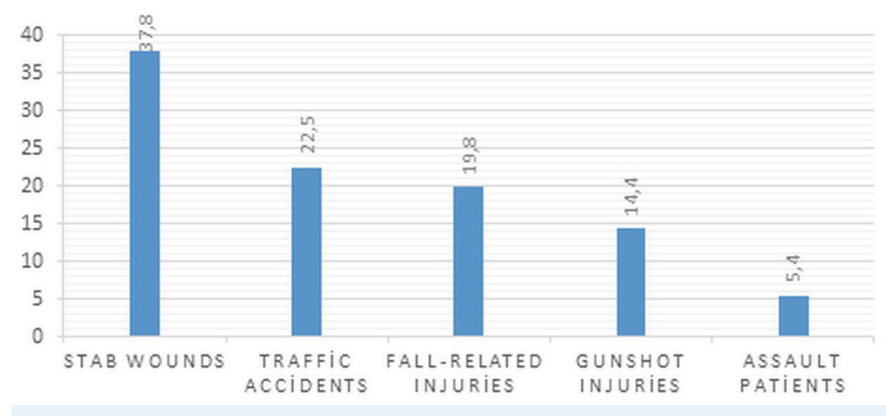

Figure 3. Etiological mechanisms in patients undergoing tube thoracostomy due to trauma 
Table 3. Thoracic injuries detected according to trauma mechanism

\begin{tabular}{|l|l|l|l|l|}
\hline Mechanism & $\begin{array}{l}\text { Hemothorax } \\
\mathbf{n}(\%)\end{array}$ & $\begin{array}{l}\text { Pneumothorax } \\
\mathbf{n}(\%)\end{array}$ & $\begin{array}{l}\text { Hemopneumothorax } \\
\mathbf{n}(\%)\end{array}$ & $\begin{array}{l}\text { Total } \\
\mathbf{n}(\%)\end{array}$ \\
\hline Traffic accidents & - & $6(24)$ & $19(76)$ & $25(100)$ \\
\hline Fall-related Injuries & $3(13.6)$ & $9(40.9)$ & $10(45.5)$ & $22(100)$ \\
Assault patients & $1(16.7)$ & $4(66.7)$ & $1(16.7)$ & $6(100)$ \\
Gunshot injuries & $13(81.3)$ & - & $3(18.8)$ & $16(100)$ \\
Stab wounds & $31(73.8)$ & $8(19)$ & $3(7.1)$ & $42(100)$ \\
\hline
\end{tabular}

male and 42 (19.5\%) were female. In a study including 57 patients conducted by Bailey ${ }^{(13)}, 74 \%$ of the patients who underwent TT were male and 26\% were female. In another study including 269 cases by Sethuraman et al. ${ }^{(14)}, 78.5 \%$ of the patients were men and $21.5 \%$ were women. Consistent with the data in literature, $85.2 \%$ of the 263 patients who underwent TT in the present study were male and the remaining $14.8 \%$ were female.

Pneumothorax cases with spontaneous or traumatic causes frequently present in the EDs and TT procedures are applied in such cases. In a study conducted by Ince et al. (15) on 129 patients who underwent TT due to diagnosis of pneumothorax, 106 (82.2\%) were male and 23 (17.8\%) were female. In the present study, 145 (83.3\%) of the 174 patients who underwent TT due to diagnosis of pneumothorax were male and 29 (16.7\%) were female. In a study on 164 patients with spontaneous pneumothorax conducted by Gök et al. ${ }^{(16)}$, $87.8 \%$ were male and $12.2 \%$ were female. In a study including 260 patients with spontaneous pneumothorax by Karasu et al. ${ }^{(17)}, 87.3 \%$ were male and $12.7 \%$ were female. In our study, the 134 patients who underwent TT due to diagnosis of spontaneous pneumothorax comprised 117 (87.3\%) males and 17 (12.7\%) females. In our study population, 19 (70.4\%) of the 27 patients who underwent TT due to diagnosis of traumatic pneumothorax were male. Consistent with the data in literature, in the present study, the patients who underwent TT due to diagnosis of pneumothorax included a higher percentage of males than females.

Many trauma patientswho are injured via different mechanisms, including traffic accidents, falls, stabbings, and gunshots, are evaluated in the ED and these patients sometimes develop pneumothorax, hemothorax, or hemopneumothorax due to thoracic trauma, thus requiring TT. In a study conducted by SIrmalı ${ }^{(18)}, 74(87.1 \%)$ of 85 patients who underwent TT in the ED after trauma were male, whereas 11 (12.9\%) patients were female. In another study by Leblebici et al. ${ }^{(19)}, 87 \%$ of the patients with thoracic trauma were male. In a study conducted by Altunkaya et al. ${ }^{(20)}, 85 \%$ of the patients hospitalized after thoracic trauma were male. In the present study, 95 (85.6\%) of the 111 patients who underwent TT in the ED after trauma were male and the remaining 16 (14.4\%) patients were female. As reported in previous studies, in the present study, the rates of thoracic trauma and consequent TT were significantly higher in men than women.

The mean age of patients undergoing TT in the ED was 37 years in a study by Chan et al. (21), 43 years in a study by Bailey ${ }^{(13)}, 35$ years in a study by Sethuraman et al. ${ }^{(14)}, 44.2$ years in a study by Șentürk et al. ${ }^{(12)}$, and $35.89 \pm 17.47$ years in the present study. Thus, patients undergoing TT in the ED are generally young and the mean age differences among the studies may be due to the population distributions in the regions where the studies were conducted.

In trauma patients, pneumothorax is the most common indication for emergency $T T^{(11-13)}$. Şentürk et al. ${ }^{(12)}$ reported that TT was performed in 113 patients due to pneumothorax, 76 patients due to hemothorax, 17 patients due to hemopneumothorax, and 10 patients due to pleural effusion. In the study conducted by Bailey ${ }^{(13)}$, TT was performed due to pneumothorax in $60 \%$ of the patients, hemothorax in $20 \%$, flail chest in $18 \%$, and multiple rib fractures in $2 \%$. In the present study, TT was performed in $174(66.2 \%)$ cases due to pneumothorax, 74 (28.2\%) cases due to hemopneumothorax, $10(3.8 \%)$ cases due to hemothorax, and 5 (1.9\%) cases due to effusion and empyema. Doğan and Kalafat ${ }^{(22)}$ reported that the most common indication for TT was pneumothorax, with a rate of $66.7 \%$. Consistent with the data in literature, this rate was $66.2 \%$ in our study population.

In the study by Sethuraman et al. ${ }^{(14)}$, which includes a total of 242 patients, 201 (83\%) patients had traumatic etiologies, 37 (15.3\%) had a spontaneous pneumothorax and $2(0.8 \%)$ had an iatrogenic pneumothorax. In the study by Șentürk et al. (12), traffic accidents represented the most common mechanism responsible for 72 (33.3\%) of the 216 patients requiring TT. They reported that the responsible mechanisms were traumatic events, including traffic accidents, falls, assaults, gunshots, and stabbings in 177 of the 216 cases requiring TT. 
In a retrospective study of 114 patients, Aydın (23) showed that majority of the TT cases were due to spontaneous pneumothorax and subsequent traumatic pneumothorax following traffic accidents or falling from a height. In their study, majority of the patients undergoing TT due to both spontaneous pneumothorax and traumatic pneumothorax were male. Consistent with the data in literature, with regard to the mechanisms responsible for the indication for TT, 134 (51\%) of the 263 patients were diagnosed with spontaneous pneumothorax. Of the 111 (42.2\%) patients with injuries due to trauma, 12 (4.6\%) developed a spontaneous pneumothorax. Of those diagnosed with iatrogenic pneumothorax, 5 (1.9\%) patients had comorbid diseases and infections, which were responsible for the formation of effusions, and 1 patient had pneumothorax caused by barotrauma. In addition, 224 $(85.2 \%)$ of the patients in our study were male.

The etiologies of pneumothorax in our study population were spontaneous pneumothorax in 134 (77\%) cases, traumatic pneumothorax in 27 (15.5\%) cases, iatrogenic pneumothorax in $12(6.9 \%)$ cases, and pneumothorax due to barotrauma in $1(0.6 \%)$ case. In their series of 318 cases, Melton et al. ${ }^{(24)}$ reported that 77 (24.2\%) patients developed primary spontaneous pneumothorax, 64 (20.1\%) developed secondary spontaneous pneumothorax, 75 (23.5\%) developed traumatic pneumothorax, and 102 (32\%) developed iatrogenic pneumothorax. In a study by Sethuraman et al. (14), TT was performed due to traumatic pneumothorax, spontaneous pneumothorax, and iatrogenic pneumothorax in $59 \%, 37 \%$, and $1.6 \%$ of the cases, respectively. In a study by Ince et al. (15), $68.2 \%$ of the patients had a spontaneous pneumothorax and $31.8 \%$ had traumatic pneumothorax. In the same study, iatrogenic pneumothorax was observed at a rate of $21.95 \%$ and evaluated as traumatic pneumothorax. There were differences in the rates of traumatic and spontaneous pneumothorax between studies conducted in different centers, since secondary spontaneous pneumothorax is an important cause of pneumothorax due to the more widespread use of immunosuppressive drugs in developed countries. Furthermore, the size of the elderly population, rate of opportunistic infections, and admission rate of trauma cases differ according to the geographical regions where the study centers are located, and the technical capabilities of the staff and equipment available at each center play a vital role.

With regard to risk factors, pneumothorax is six times more common in men and male smokers compared with women and non-smokers. This sex-related difference is decreasing simultaneously with an increase in the rate of smoking among women. We evaluated the incidence of smoking in patients with a spontaneous pneumothorax who underwent TT in the given literature. Demirhan et al. ${ }^{(25)}$ conducted a study on 274 patients with primary spontaneous pneumothorax, reporting that 216 (78.8\%) of these patients had a history of smoking. Moreno-Merino et al. ${ }^{(26)}$ reported that 447 (56.8\%) of 787 patients with primary spontaneous pneumothorax had a history of smoking. In our study population, 81 (60.4\%) of the 134 patients diagnosed with spontaneous pneumothorax had a history of smoking, whereas the remaining 53 patients (39.6\%) were non-smokers. According to the data in literature, the risk of spontaneous pneumothorax is 22 times higher in male smokers and 9 times higher in female smokers than in sex-matched non-smokers. The relationship between smoking and pneumothorax is dose-dependent and the risk increases with the number of cigarettes smoked per day. Loss of function of chemotactic factor inactivators due to smoking also increases neutrophil recruitment. The recruitment of inflammatory cells results in high pressure in the pulmonary alveolar tissue, leading to rupture and development of pneumothorax ${ }^{(27)}$. Consistent with the data in literature, the proportion of patients with a history of smoking was higher among those undergoing TT due to diagnosis of spontaneous pneumothorax in our study population.

Thirteen (65\%) of the 20 patients who underwent TT due to recurrent pneumothorax had a history of smoking, whereas the remaining 7 (35\%) patients were non-smokers. The risk of recurrence was reported to decrease in patients who quit smoking after the first pneumothorax event (40\%), but was found to be increased in those who continued to smoke $(70 \%)^{(28)}$. Chronic smoking is thought to increase the risk of recurrent pneumothorax, since it causes inflammation and edema in the distal airway and increases the rates of chronic obstructive pulmonary disease and similar emphysematous diseases.

Primary spontaneous pneumothorax has been reported to be more common on the right side compared with the left side ${ }^{(29)}$. Gibney et al. ${ }^{\left({ }^{30}\right)}$ reported that primary spontaneous pneumothorax occurred on the right side in 141 (55.1\%) of 173 patients. Consistent with previous studies, in the present study, 73 (54.5\%) of 134 patients exhibited pathologies in the right hemithorax and 61 (45.5\%) in the left hemithorax. The predominance of spontaneous pneumothorax on the right side may be because the right lung has a larger surface area relative to the left lung.

With regard to the relationship between blunt and penetrating trauma and an indication for TT, Şentürk 
et al. (12) reported that 72 of the 142 patients with blunt trauma were diagnosed with pneumothorax, 55 were diagnosed with hemothorax, 13 were diagnosed with hemopneumothorax, and 2 were diagnosed with pleural effusion. Of the 35 patients with penetrating injuries included in the same study, 14 were diagnosed with pneumothorax, 17 were diagnosed with hemothorax, and 4 were diagnosed with hemopneumothorax. Of the 53 patients with blunt trauma included in the present study, 4 (7.5\%) were diagnosed with hemothorax, 19 (35.8\%) were diagnosed with pneumothorax, and 30 (56.6\%) were diagnosed with hemopneumothorax, whereas hemothorax was detected in $6(10.3 \%)$, pneumothorax was detected in $8(13.8 \%)$, and hemopneumothorax was detected in 44 (75.9\%) of the 58 patients with penetrating trauma. These findings indicate that penetrating injuries more frequently cause hemorrhagic outcomes.

Çobanoğlu (31) reported that the most common pathology in thoracic injuries was rib fractures, with a rate of $41.8 \%$. In the same study, single or multiple rib fractures were shown to often accompany injuries resulting from blunt trauma, with $1-2, \geq 3$, and bilateral rib fractures in $28.2 \%, 26.3 \%$, and $3.6 \%$ of the patients, respectively. In the present study, single or multiple rib fractures were detected in $33.3 \%$ of the patients who underwent TT after trauma. No fractures were detected in $18(34 \%)$ of the 53 patients with blunt trauma injuries in our study, whereas $2(3.8 \%)$ patients had single rib fractures, $32(60.4 \%)$ had multiple rib fractures, and 1 (1.9\%) had a scapula fracture. Therefore, a total of 35 patients $(66 \%)$ had single or multiple rib fractures in the present study. The fracture rates in the present study were consistent with those in literature and the results suggest that blunt trauma causes more fractures compared with penetrating trauma and that these fractures increase the risk of intrathoracic injury.

Although TT is an essential life-saving procedure, it can lead to complications even when performed by experienced hands. Etoch et al. ${ }^{(32)}$ suggested that the complications of TT depend on the physician performing the procedure and the equipment available in the surgical unit, regardless of the cause or severity of the trauma. They also suggested that the risk of complications would be double for TT procedures performed by non-thoracic surgeons. Complication rates have been reported to range between $1 \%$ and $40 \%$ in the literature $(11,12,14,22,32)$. Complications developed in $21.4 \%$ of the cases in the study conducted by Doğan and Kalafat ${ }^{(22)}$ Whereas all of the complications in their study occurred in procedures performed by emergency medicine specialists, there were no complications associated with the procedures performed by pediatric surgeons $(n=2)$ or a thoracic surgeon $(n=1)$.

Etoch et al. ${ }^{(32)}$ reported complication rates of $13 \%$ and $6 \%$ in TT performed under ED conditions by emergency physicians and surgeons, respectively. Sethuraman et al. ${ }^{(14)}$ reported a complication rate of $19.4 \%$ for TT performed by emergency medicine residents. Chan et al. ${ }^{(21)}$ compared the prevalence of complications from TT procedures performed in the ED, operating room, and chest surgery room and reported rates of $14 \%, 9.2 \%$, and $25.3 \%$, respectively. In a study by Șentürk et al. ${ }^{122}$, where all the TT procedures were performed by thoracic surgeons, the complication rate was $18 \%$. In the present study evaluating 263 TT procedures performed by emergency physicians, complications developed in only 8 (3\%) patients. Of the patients with complications, empyema developed in $2(0.8 \%)$ and subcutaneous emphysema in another $2(0.8 \%)$ cases. The tube was displaced in 3 patients $(1.1 \%)$ and the procedure failed in $1(0.4 \%)$ patient. Complications developed in $4 \%$ of the 174 pneumothorax patients and $1.4 \%$ of the 74 hemopneumothorax patients in the present study. The results of the present study suggest that the development of complications in TT procedures is not related to the specialty of the medical practitioner and that the complication rates can be reduced with sufficient knowledge and experience.

Empyema has been reported as a major complication of $\mathrm{TT}$, with the rate of occurrence ranging from $2 \%$ to $6 \%$ ${ }^{(33,34)}$. Chan et al. (21) reported that empyema occurred at a rate of $1 \%$. Sethuraman et al. ${ }^{(14)}$ reported that empyema developed in $2(2.2 \%)$ of the 90 patients undergoing TT procedures in the ED. Consistent with the data in literature, in the present study, the incidence of empyema was $0.8 \%$. The incidence of empyema varies according to the mechanism of trauma and can be reduced using appropriate prophylactic antibiotics to ensure sterility of the surgical field.

\section{CONCLUSION}

In conclusion, TT is performed in the ED more frequently in men compared with women and the most common etiologies are pneumothorax and non-traumatic causes. In addition, the application of TT procedures by emergency physicians did not increase the rate of complications, which can be maintained at $\sim 3 \%$ by practitioners with sufficient knowledge and experience following appropriate sterility protocols. 


\section{Ethics}

Ethics Committee Approval: The study protocol was initiated after obtaining approval from the University of Health Sciences Turkey, Şişli Hamidiye Etfal Training and Research Hospital Ethics Committee on October 18, 2016 with the approval number 1289.

Informed Consent: Retrospective study.

Peer-review: Externally peer reviewed.

\section{Authorship Contributions}

Concept: H.E., B.K.Y., Design: H.E., B.K.Y., Data Collection or Processing: H.E., B.K.Y., Analysis or Interpretation: H.E., B.K.Y., Literature Search: H.E., B.K.Y.,

Writing: H.E., B.K.Y.

Conflict of Interest: No conflict of interest was declared by the authors.

Financial Disclosure: The authors declared that this study received no financial support.

\section{REFERENCES}

1. Rosenblatt M, Robalino J, Bergman A, Shevde K. Pleural block: technique for regional anesthesia during percutaneous hepatobiliary drainage. Radiology. 1989;172:279-80. doi: 10.1148/radiology.172.1.2740515.

2. Rusch VW, Figlin R, Godwin D, Piantadosi S. Intrapleural cisplatin and cytarabine in the management of malignant pleural effusions: a Lung Cancer Study Group trial. J Clin Oncol. 1991;9:313-9. doi: 10.1200/ JCO.1991.9.2.313.

3. Ergin M, Yeğinsu A, Gürlek K. Ulusal Cerrahi Dergisi. 2010;26:115-21.

4. Iberti TJ, Stern PM. Chest tube thoracostomy. Crit Care Clin. 1992;8:879-95.

5. Cho DY, Sohn DS, Cheon YJ, Hong K. Complications of a Tube thoracostomy performed by emergency medicine residents. J Korean Soc Traumatol. 2012;25:37-43.

6. Dural K, Gulbahar G, Kocer B, et al. A novel and safe technique in closed tube thoracostomy. J Cardiothorac Surg. 2010;5-21. doi: 10.1186/17498090-5-21.

7. Baldt MM, Bankier AA, Germann PS, et al. Complications after emergency tube thoracostomy: Assessment with CT. Radiology. 1995;195:539-543. doi: 10.1148/radiology.195.2.7724780.

8. Kesieme EB, Dongo A, Ezemba $\mathrm{N}$, et al. Tube thoracostomy: complications and Its management. Pulm Med. 2012;2012:256878. doi: 10.1155/2012/256878.

9. Shlamovitz GZ. Tube thoracostomy: Medscape Reference. Last Accessed Date: 24.02.2020. Available from: https://emedicine.medscape.com/ article/80678-overview.

10. Ülkü R. Toraks travmalı hastada acil departman torakotomisi ve tüp torakostomi. TTD Toraks Cerrahisi Bülteni. 2010;1:19-28.

11. Menger R, Telford G, Kim $P$, et al. Complications following thoracic trauma managed with tube thoracostomy. Injury 2012;43:46-50. doi: 10.1016/j.injury.2011.06.420.

12. Șentürk E, Bulut A, Türe $M$, Yoldaș E, Doğan Y. Acil Tüp Torakostomi Uygulamalarında Morbidite Turkiye Klinikleri Arch Lung. 2011;12:1-8.

13. Bailey RC. Complications of tube thoracostomy in trauma. J Accid Emerg Med. 2000;17:111-4. doi: 10.1136/emj.17.2.111.
14. Sethuraman KN, Duong D, Mehta $S$, et al. Complications of tube thoracostomy placement in the emergency department. J Emerg Med 2011;40:14-20. doi: 10.1016/j.jemermed.2008.06.033.

15. Ince A, Ozucelik DN, Avci A, et al. Management of pneumothorax in emergency medicine departments: multicenter trial. Iran Red Crescent Med J. 2013;15:el1586. doi: 10.5812/ircmj.11586

16. Gök M, Ceran S, Sunam G, Uzun K. Spontan pnömotorakslı olguların değerlendirilmesi. Tıp Araştırmaları Dergisi. 2007;5:27-30.

17. Karasu S, Tokat AO, Kisacik E, et al. Spontaneous Pneumothorax: analysis of 260 Patients. J Clin Anal Med. 2012;3:174-7.

18. Sırmalı M. Tüp torakostomi uygulanan toraks travmalı 85 hastanın analizi. SDÜ Tıp Fakültesi Dergisi. 2013;20:54-7.

19. Leblebici IH, Kaya Y, Koçak AH Göğüs travmalı 302 olgunun analizi. Türk Göğüs Kalp Damar Cerrahisi Dergisi. 2005;13:392-6.

20. Altunkaya A, Aktunç $E$, Kutluk $A C$, et al. Analysis of 282 patients with thoracic trauma. Türk Göğüs Kalp Damar Cerrahisi Dergisi. 2007;15:127-32.

21. Chan L, Reilly KM, Henderson C, Kahn F, Salluzzo RF. Complication rates of tube thoracostomy. Am J Emerg Med. 1997;15:368-370.

22. Doğan S, Kalafat UM. Retrospective evaluation of patients who underwent tube thoracostomy at the emergency department: one year analysis. IKSST Derg. 2018;10(3):122-7. doi:10.5222/ iksst.2018.03016

24. Aydın İ. Acil serviste tüp torakostomi uygulanan hastaların sonuçları. Adıyaman Üniversitesi Sağlık Bilimleri Dergisi. 2020;6:47-53. doi: 10.30569/adiyamansaglik.635411

25. Melton LJ 3rd, Hepper NG, Offord KP. Incidence of spontaneous pneumothorax in Olmsted County, Minnesota: 1950 to 1974. Am Rev Respir Dis. 1979 ;120(6):1379-82. doi: 10.1164/arrd.1979.120.6.1379

26. Demirhan $R$, Koşar A, Eryiğit $H$, et al. Spontaneous pneumothorax: retrospective analysis of 348 cases. Ulusal Travma Acil Cerrahi Derg. 2009;15(4): 367-70.

27. Moreno-Merino S, Congregado M, Gallardo G, et al. Comparative study of talc poudrage versus pleural abrasion for the treatment of primary spontaneous pneumothorax. Interact Cardiovasc Thorac Surg. 2012;15:81-5. doi: 10.1093/icvts/ivs027.

28. Schramel FM, Postmus PE, Vanderschueren RG. Current aspects of spontaneous pneumothorax. Eur Respir J. 1997;10:1372-9. doi: 10.1183/09031936.97.10061372.

29. Sadikot RT, Greene T, Meadows K, Arnold AG. Recurrence of primary spontaneous pneumothorax. Thorax. 1997;52:805-9. doi: 10.1136/ thx.52.9.805.

30. Brooks JW. Open thoracotomy in the management of spontaneous pneumothorax. Ann Surg. 1973;177:798-805. doi: 10.1097/00000658197306000-00020.

31. Gibney RTN, Finnegan B, FitzGerald MX, et al. Upper airway obstruction caused by massive subcutaneous emphysema. Intensive Care Med 1984;10:43-4. doi: 10.1007/BF00258069.

32. Çobanoğlu U. Göğüs travması: 110 olgunun analizi. Toraks Dergisi. 2006;7:162-9.

33. Etoch SW, Bar-Natan MF, Miller FB, Richardson JD. Tube thoracostomy. Factors related to complications. Arch Surg. 1995;130(5):521-5; discussion 525-6. doi: 10.1001/archsurg.1995.01430050071012.

34. Yıldızeli $B$, Yüksel M. Surgical techniques in pleura. Turk Thorac J 2002;3:27-41

35. Heniford BT, Carrillo EH, Spain DA, et al. The role of thoracoscopy in the management of retained thoracic collections after trauma. Ann Thorac Surg. 1997;63:940-3. doi: 10.1016/s0003-4975(97)00173-2. 